\title{
KIRJOITUS
}

ANNA SOFIA SALONEN

\section{Ruoka-apu, mielikuvitus ja tulevaisuus}

Kirjoitus perustuu Mikkelin biippakunnan ja Työttömien Keskusjärjestön toteuttamassa työttömyystyön päivässä 27.8.2020 Päivärannan kurssikeskuksessa Imatralla pidettyyn esitelmään. Kirjoituksen lybyempi versio on julkaistu Työttömien keskusjärjestön vierasblogissa 4.9.2020. bttps://tyottomat.fi/tiedotteet/kriisi-haastaa-mielikuvittelemaan-ruoka-avun-tulevaisuuttal

Mitä päätät tehdä (tai jättää tekemättä) perustuu suureksi osaksi siihen, mitä voit kuvitella tekeväsi: mikä on mahdollista, tärkeää, oikein ja toteutettavissa olevaa. (Perrin 2006:2, käännös kirjoittajan.)

Kun puhun yleisötilaisuuksissa ruoka-apua vastaanottavien ihmisten kokemusmaailmasta, pyydän toisinaan kuulijoitani mukaan mielikuvitusharjoitukseen (Salonen, 2016c). Harjoituksessa eläydymme ensin omaan arkiseen ruoanhankintaan ostoslistoineen, mielitekoineen, laihdutuskuureineen, hoivavastuineen ja kauppareissuineen. Tämän jälkeen kokemus rinnastetaan ruoka-avun vastaanottamisen käytäntöihin: jonottamiseen, odottamiseen, valmiisiin ruokakasseihin ja yllätystuotteisiin, vaille jäämiseen ja ehkä virren veisuuseen. Tällainen arkisen ja vieraan rinnastava mielikuvittelu voi auttaa orientoitumaan aiheeseen ja eläytymään toisen asemaan.

Tänä keväänä mielikuvitus murtautui todellisuuteen varsin dystooppisessa muodossa. Kun koronaviruspandemia puhkesi, uutisemme täyttyivät kuvilla kauppojen tyhjistä hyllyistä. Yhtäkkiä ei ollutkaan itsestään selvää, että kau- 
pasta sai ostettua koska vain mitä vain; wc-paperia, pastaa tai säilykkeitä. Tai että kauppaan oli ylipäänsä asiaa. Kun koronavirus puhkesi, puheemme täyttyi poikkeustilasta, joka muutti monia itsestään selvinä pitämiämme arkisia rutiineja ja vaikutti muun muassa tapaamme hankkia ja kuluttaa ruokaa.

Kun koronapandemian myötä pystytettyjä rajoituksia alettiin purkaa kesäkuussa, uutisissa kerrottiin pitkästä aikaa maanantaina ulos ravintolaan lounaalle päässeistä ihmisistä. Näille ihmisille maanantainen ravintolalounas merkitsi odotettua paluuta normaaliin tai ainakin niin sanottuun uuteen normaaliin.

Medialla on taipumus luoda ihmiset omaksi kuvakseen, tässä tapauksessa valinnanvapauden kaventumisen kohteeksi joutuneeksi kuluttajaksi tai ulkona lounastavaksi toimistotyöläiseksi. Mutta ketkä jäävät kuvan ulkopuolelle? Millaista on uusi normaali niille, joiden ruokahyllyt ovat tyhjät aina kuun lopussa? Niille, jotka seisovat runsaina notkuvien hyllyjen välissä, mutta joilla ei ole varaa ostaa ruokaa? Niille, joille ulkona syöminen on aina ollut kaukainen haave? Niille, joiden sosiaalinen elämä rakentui ennen kahviloissa ja ravintoloissa käymisen varaan, mutta jotka lomautusten, irtisanomisten tai konkurssien vuoksi joutuvat nyt väliaikaisesti tai pysyvästi näiden elämänpiirien ulkopuolelle?

\section{Ruoka-apu yhteiskunnallisena tunnusmerkkinä}

Uusimman sosiaalibarometrin (2020) mukaan ruoka-avun tarve kasvoi koronakriisin myötä. Monet sosiaalityöntekijät raportoivat ruoka-avun tarpeen kasvaneen ja esimerkiksi evankelis-luterilaisen kirkon tilastojen mukaan ruokakassien jako kaksinkertaistui tämän vuoden huhtikuussa verrattuna helmikuun lukuihin.

Ruoka-avun tarpeen muutokset yhdistetään usein suoraviivaisesti toimeentulo-ongelmien ja huono-osaisuuden määrälliseen muutokseen.”Leipäjonot pitenevät" ja "ruoka-avun tarve kasvaa" ovat laajalti viljeltyjä otsikoita taloudellisista laskusuhdanteista uutisoitaessa. Tällaiset ruoka-avun tarpeen kasvuun viittaavat huomiot ikään kuin validoivat abstraktien talouslukujen inhimilliset vaikutukset. Kansainvälinen tutkimus on kuitenkin osoittanut, ettei köyhyyden, huono-osaisuuden ja ruokaturvattomuuden lisääntyminen tai väheneminen ole suoraan verrannollinen ruoka-avun asiakasmäärien kasvuun tai laskuun (Loopstra \& Tarasuk, 2015). Tämä johtuu muun muassa sii- 
tä, että ruoka-apu ei tavoita kaikkia sitä tarvitsevia, eivätkä kaikki ruoka-avun kohderyhmään kuuluvat halua ottaa apua vastaan.

Vaikka tutkimus on osoittanut, että ruoka-avun käyttö on kehno indikaattori mitattaessa köyhyyttä ja ruokaturvan puutteita, heijastavat sen äkilliset muutokset yhteiskunnallisia muutoksia erityisesti kriisitilanteissa, joissa akuutin aineellisen avun tarve kasvaa nopeammin kuin yhteiskunnan muut tukiverkot voivat siihen vastata. Itse ajattelen, ettei ruoka-apu ole niinkään määrällinen, vaan ennen kaikkea laadullinen yhteiskuntamme tilan mittari.

Yle uutisoi kesäkuussa, että "Leipäjonoissa käy nyt tavallisia työikäisiä" (Yle 11.6.2020). Kuvan uutisotsikko on paljastava. Se että ruoka-apuun turvautuvat nyt tavalliset ihmiset, antaa ymmärtää, että ruoka-apuun turvautuivat ennen toiset, epätavalliset, muut. Niin mediassa kuin tutkimuksessa, kirkossa ja yhdistyksissäkin olemme tottuneet puhumaan avun tarpeessa olevista toisista: haavoittuvista yksilöistä ja huono-osaisista ryhmistä. Jos koronakriisi on meille jotain opettanut niin sen, että me kaikki elämme epävarmuudessa. Yhteiskuntajärjestelmämme on havoittuvainen ja koko elämänmuotomme uhanalainen. Kriisi ei koske vain joitakuita huono-onnisia, jotka putoavat vakaalta pohjalta, vaan pohja itse on hauras.

Ruoka-apu ei ole vastaus. Se ei vain vastaa ulkopuolelta tulevaan kriisiin, vaan on osa sitä yhteiskunnallista järjestystä, jonka viitekehyksessä kriisit syntyvät ja jonka hegemonista asemaa ne uhkaavat. Sen sijaan että ruoka-apua ajateltaisiin vastauksena johonkin yhteiskunnalliseen ongelmaan, on sitä hedelmällisempää lähestyä yhteiskunnallisena symbolina tai tunnusmerkkinä, joka herättää kysymyksiä maailmamme tilasta.

\section{Ruoka-apu, hyvinvointiyhteiskunta ja runsaus}

Kun ruoka-apu ilmestyi suomalaiseen yhteiskuntaan ja katukuvaan 1990-luvun laman seurauksena, ilmiö kehystettiin osaksi hyvinvointivaltion kriisiä. Ruoka-apu oli hyvinvointiyhteiskunnan "avohaava", ja ruokapankki "pankki, jota ei pitäisi olla”. Ruoka-avun katsottiin osoittavan, ettei tuki- ja palvelujärjestelmä toimi kuten sen hyvinvointivaltioeetoksen mukaan kuuluisi. Ihanneyhteiskunnassa kaikilla olisi riittävä toimeentulo, eikä vapaaehtoisuuteen tai armeliaisuuteen perustuvaa laajamittaista aineellista apua tarvittaisi (Karjalainen, 2008). Ruoka-avun tehtävänä oli tehdä itsestään tarpeeton. 
Näin ei kuitenkaan käynyt. Ruoka-avun vakiinnutettua paikkansa suomalaisessa yhteiskunnassa keskustelun kehys on muuttunut. Nykyään puhutaan vähemmän siitä, ettei ruoka-apua pitäisi olla olemassakaan, ja enemmän siitä, kuinka sitä voitaisiin jakaa tehokkaammin ja paremmin. Tähän kysymykseen liittyy likeisesti hävikkiruoan hyötykäyttö ruoka-avun resurssina (Tikka, 2019; Salonen, 2018).

Kun lähdin vuonna 2012 keräämään tutkimusaineistoa ruoka-avun asiakkaiden kokemuksia käsittelevää väitöskirjaani (Salonen, 2016b) varten, olin valmistautunut kohtaamaan vaikeissa taloudellisissa ja sosiaalisissa tilanteissa ja puutteessa eläviä ihmisiä. En kuitenkaan ollut valmistautunut siihen ruoan runsauteen, johon törmäsin. Tutkimissani paikoissa ruoka-avun visuaalista tilaa hallitsi usein ruoan runsaus, joka asettui jännitteiseen suhteeseen ihmisten moninaisten tarpeiden kanssa. Tutkimukseni ruoka-apua vastaanottavien ihmisten parissa sai minut huomaamaan, etteivät puute ja runsaus ole Suomessa toisensa poissulkevia asioita. Ruoka-avun todellisuudessa ne lyövät kättä. Tutkimuksessani havaitsin kouriintuntuvasti, kuinka ruoka on samaan aikaan niin halpaa, että sitä voidaan heittää pois, ja niin kallista, ettei kaikilla ole siihen varaa (Salonen, 2016a). Ruoka-apu ei ole vastaus elintarvikehävikin ja ylijäämän ongelmaan, vaan osoitus siitä vakavasta kohtaanto-ongelmasta, joka vallitsee kysynnän, tarpeiden ja tarjonnan välillä ja jolla on syviä sosiaalisia ja ekologisia seurauksia.

\section{Ruoka-avun monitahoinen yhteisöllisyys}

Ruoka-avun ja ylijäämän yhtymäkohtien lisäksi nykyään keskustellaan paljon ruoka-avun yhteisöllisyydestä. Maanlaajuisessa ruoka-avun asiakkaiden kokemuksia kartoittaneessa kyselytutkimuksessa kävi ilmi, että noin puolet avun saajista piti ruoka-avun sosiaalista ulottuvuutta, muiden ihmisten kohtaamista tärkeänä osana tätä toimintaa (Kainulainen, 2014). Tämän tuloksen voidaan tulkita puhuvan sen puolesta, että ruoka-apu on monelle sen saajalle "enemmän kuin leipää". Se on myös tärkeää sosiaalista ja yhteisöllistä toimintaa.

Tutkijana oma huomioni kiinnittyi kuitenkin myös tuloksen toiseen puolikkaaseen. Noin puolelle vastaajista muiden ihmisten kohtaaminen ei ollut tärkeää. Mitä se siis oli? Oliko se merkityksetöntä? Liittyikö siihen vaaroja? 
Osallistuva tutkimukseni ruoka-avun asiakkaiden parissa osoitti, että ruoka-avun sosiaalisuus on moniulotteista: Ruoka-apu on sekä valvova, vaativa, että merkittävä yhteisö (Salonen, 2017). Moni ruoka-apupaikka esimerkiksi toimii matalan kynnyksen periaatteella, jossa yksilön ei tarvitse todistaa tarvitsevuuttaan. Tämä tekee avun hakemisen helpommaksi, mutta samalla saattaa johtaa avun saajien väliseen keskinäiseen tarkkailuun, arvosteluun ja kyräilyyn. Jonossa seisoen odottaminen voidaan kokea raskaaksi, mutta toisaalta erilaiset sisälle organisoidut vapaammat odottamisen tavat voivat yllättäen muodostua sosiaalisen kanssakäymisen vuoksi kuormittaviksi ja herättää kysymyksiä oikeudenmukaisesta avun saamisen järjestyksestä. Ruoka-apua kritisoidaan nykyään useimmiten sen näkyvimmästä muodosta: niin sanotusta leipäjonosta. Jonossa odottaminen tarkoittaa näkyville asettumista ja sisältää siksi leimaamisen ja leimautumisen vaaran. Jono mahdollistaa selän kääntämisen ja torjutuksi tulemisen, mutta se voi myös mahdollistaa kohtaamisen ja kokemuksen samassa veneessä olemisesta. Jopa sen nurjimmissa muodoissa, ruoka-apu on myös merkityksellinen paikka.

Ruoka-aputoiminta on vääjäämättä yhteisöllistä, mutta yhteisöllisyyden luonne ja siihen liittyvät mahdollisuudet ja haasteet ilmenevät eri tavoin riippuen siitä, miten apu on käytännössä järjestetty. Tutkimukseni huomioi sen, että ruoka-avun käytännön organisointityöllä on merkitystä sille, kokevatko avun vastaanottajat tilanteen sosiaalisesti kontrolloivana ja valvovana, vaativana ja kuormittavana vai merkittävänä ja myönteisessä mielessä merkityksellisenä toimintana.

\section{Mielikuvitus ja ruoka-avun tulevaisuus}

Yhdysvaltalainen sosiologi Andrew Perrin (2006) käyttää käsitettä "demokraattinen mielikuvitus" viitatessaan käsityksiin ja ajatuksiin siitä, mikä on mahdollista, tärkeää, oikein ja toteutettavissa olevaa. Demokraattisen mielikuvituksen taustalla on ajatus, että aktiivinen kansalaisuus ei ole vain tekemistä ja sitoumusten ja vastuun toteuttamista, vaan myös vastuun ja sitoumusten ajattelemista ja niistä puhumista. Tällainen ajattelu ja puhe tarjoavat materiaalia ja mahdollisuuden kuvitella uusia kansalaistoiminnan muotoja, ja siten tuottaa uusia välineitä yhteiskunnallisten ongelmien ratkaisuun. Yhteiskunnallinen keskustelu ja tutkijoiden ja järjestökentän välinen vuorovaikutus ovat osa tätä uutta luovaa toimintaa. Koronakriisin myötä kärjistyneet toimeentu- 
lo-ongelmat ja aineellisen avun tarve eivät haasta vain niitä ihmisiä, jotka ovat avun tarpeessa, vaan myös avun tarjoajia, avun tutkijoita, koko yhteiskuntaa ja meidän mielikuvitustamme.

Ruoka-apua jakavat yhdistykset ja seurakunnat ovat keskeisessä roolissa sekä oman toimintansa tulevaisuuden suuntaviivojen hahmottajina että yhteiskunnallisten kysymysten esille tuojina, asettajina ja muovaajina. Kriisi haastaa kuvittelemaan vastauksia suuriin kysymyksiin. Tutkijana toivon voivani haastaa ruoka-apukentällä toimivia yhteisöjä ja yksilöitä kuvittelemaan vastauksia esimerkiksi seuraaviin kysymyksiin:

Voisivatko uuden normaalin myötä kauppojen hyllyt olla jatkossakin vain puoliksi täynnä, ja mitä tämä tarkoittaisi ekologiselle kestävyydelle, ruoka-avun vastaanottajille, avun tarjoajien resursseille ja koko ruoka-aputoiminnan tulevaisuudelle?

Kuinka luoda ruoka-avun jaosta turvallinen yhteisöllinen tila ja sosiaalinen tapahtuma, joka ei leimaa tai kuormita yksilöä?

Kuinka ylläpitää ruoka-aputoimintaa tavalla, joka ei hyväksy sen enempää elintarvikeylijäämää kuin eriarvoisuuttakaan vallitsevaan yhteiskuntajärjestykseen sisältyväksi välttämättömäksi pahaksi?

Onko ruoka-apu tullut jäädäkseen vai onko meillä yhä kykyä tai tahtoa mielikuvitella se nykyisessä laajuudessaan tarpeettomaksi?

\section{Kirjallisuus}

Kainulainen, S. (2014). Ruoka-avun hakijoiden hyvinvointi. - M. Ohisalo, \& J. Saari (toim.), Kuka Seisoo Leipäjonossa? Helsinki: KAKS - Kunnallisalan kehittämissäätiö, 59-69.

Karjalainen, J. (2008). Nälkä-äläkästä nälkäryhmään. Tutkimus, ruokapankit ja politiikka lehdistössä. - S. Hänninen, J. Karjalainen, K. Lehtelä \& T. Silvasti (toim.), Toisten Pankki. Ruoka-apu Hyvinvointivaltiossa. Helsinki: Stakes, 69-114.

Loopstra, R. \& Tarasuk, V. (2015). Food bank usage is a poor indicator of food insecurity: Insights from Canada. Social Policy and Society, 14:443-455. https://doi. org/10.1017/S1474746415000184
Perrin, A. J. (2006). Citizen Speak: The Democratic Imagination in American Life. Chicago: University of Chicago Press. https://doi.org/10.7208/chicago/9780226660783.001.0001

Salonen, A. S. (2016a). The Christmas celebration of secondary consumers: Observations from food banks in Finland. Journal of Consumer Culture, 16(3):870-886. https:// doi.org/10.1177/1469540514541881

Salonen, A. S. (2016b). Food for the Soul or the Soul for Food: Users' Perspectives on Religiously Affiliated Food Charity in a Finnish City. Helsinki: Helsingin yliopisto.

Salonen, A. S. (2016c). Reaching for the world of food charity recipients: a study of 
ambiguity: Lectio praecursoria, University of Helsinki, 12th of October 2016. Diakonian Tutkimus 2016(2):206-211.

Salonen, A. S. (2017). Lining up for charity. A study of the social organization and communal qualities of breadlines in a Finnish city. International Journal of Sociology and Social Policy, 37(3/4):218-230. https://doi. org/10.1108/IJSSP-10-2015-0110

Salonen, A.S. (2018). Religion, poverty and abundance. A research comment. Palgrave communications special issue: Religion and Poverty. Palgrave Communications, 4:27. https://doi.org/10.1057/s41599018-0086-8

Tikka, V. (2019). Charitable food aid in Fin- land: from a social issue to an environmental solution. Agriculture and Human Values, 36:341-352. https://doi.org/10.1007/ s10460-019-09916-3

Sosiaalibarometri (2020). Sosiaalibarometri 2020. SOSTE Suomen sosiaali ja terveys ry. Helsinki: SOSTE. https://www.soste. fi/wp-content/uploads/2020/07/SOSTE-Sosiaalibarometri-2020.pdf - Viitattu 16.8.2020.

Yle (2020). Leipäjonoissa käy nyt tavallisia työikäisiä - avustusyhdistysten toiminnanjohtaja: "Avun tarve on räjähtänyt käsiin". Yle.fi 11.6.2020. https://yle.fi/uutiset/3-11394293 - Viitattu 16.8.2020. 